\title{
LATE BRONZE AGE MONOTYPOLOGICAL DEPOSITS OF PALSTAVE AXES BETWEEN THE HYDROGRAPHIC BASINS OF RIVERS MINHO AND AVE (IBERIAN NORTHWEST): SPATIAL CONTEXTS AND INTERPRETATIONS
}

\author{
HUGO ALUAI SAMPAIO ${ }^{(1)}$
}

\begin{abstract}
:
New interpretations to a selected set of "hoards" of palstave axes with two rings from the North-western Iberia are proposed. This task was based not only on morphological study of these objects but also on their spatial contexts of deposition.

The morphological (dimensions and weight) variations observed among the objects of a same deposit allow us to consider its formation by unique and individual objects. This reveals the use of different casting molds and alloys and, hypothetically, distinct production origins.

At the same time, the distribution of different sets appears to have relations with natural circulation corridors (rivers basins and ridges areas). These were routes known and used since long ago, which certainly promoted more than occasional encounters between distinct human groups.
\end{abstract}

Keywords: Northwestern Iberia, Late Bronze Age, Palstave axes' hoards, Inter-communitarian celebration.

Resumo:

Depósitos monotipológicos de machados de talão do Bronze Final entre as bacias hidrográficas dos rios Minho e Ave (Noroeste da Península Ibérica): contextos espaciais e interpretações

No presente trabalho são propostas novas interpretações a um conjunto de depósitos de machados de talão de dois anéis do Noroeste da Península Ibérica.

Tal tarefa teve por base o estudo morfológico dos objetos mas, também, os seus contextos de deposição.

As variações morfológicas (dimensões e peso) observadas entre objetos de um mesmo depósito permitem considerar conjuntos formados por objetos únicos e individuais. Isto revela o uso de diferentes moldes e ligas com, hipoteticamente, distintas origens produtivas.

Ao mesmo tempo, a distribuição de diferentes conjuntos parece apresentar relações com corredores naturais de circulação (bacias de rios e cumeeiras). Estas rotas seriam conhecidas e utilizadas desde longa data, certamente promovendo mais do que meros encontros casuais entre distintos grupos humanos.

Palavras-Chave: Noroeste da Península Ibérica, Idade do Bronze Final, Depósitos de machados de talão, Celebração intercomunitária.

\begin{abstract}
"It is also acknowledged that prehistoric social actors occasionally drew upon meanings ascribed to objects, meanings generated through contexts of production, use and association, in order to construct particular material 'statements' through

deposition. Depositing things in the ground therefore served on occasions as a very deliberate strategy in the negotiation of values. Such statements might relate to the identity of places, the definition of different kinds of personhood or being, or the working of relations and obligations".
\end{abstract}

J. POLLARD (2001: 316)

\section{INTRODUCTION}

The present work suggests new interpretations to a previous selected group of hoards recovered in the Northwest of Iberia, specifically from the Portuguese Northwest and part of Galicia, near to the Portuguese border. This analysis included not only the morphological and chemical features of all objects but also the spatial contextualization of each set.

It is important to clarify that the mentioned geographical area includes other pluritypological depositions of hoards, weather or not combining palstave axes with other kinds of objects. However it is easier to identify particularities and/or similitudes between identical objects in a same set rather than in heterogeneous groups of materials. For this reason in this work we aim to test new approaches to a specific set of monotypological depositional manifestations.

As such, the selected group of hoards considered sets formed by two or more palstave axes with two rings, generically dating back to regional Late Bronze Age. Their recovering occurred in different

${ }^{(1)}$ Landscape, Heritage and Territory Laboratory. Escola de Arquitetura, Universidade do Minho, Campus de Azurém, 4800-058 Guimarães. Email: hugoaluai@gmail.com. 
geographic areas: from the district of Oporto, it were included the hoards of Abelheira/S. Martinho do Bougado (parish of S. Martinho do Bougado, county of Trofa) and Pinheiro/Senhora Aparecida (parish of Pinheiro, county of Felgueiras); from the district of Viana do Castelo, the hoards of Co- bidalto (parish of Areosa, county of Viana do Castelo), Carpinteira/S. Paio (parish of S. Paio, county of Valença) and Gingleta/Ganfei (parish of Ganfei, county of Melgaço); finally, from the province of Pontevedra, the hoard of Cabeiras (parish of Cabeiras, county of Arbo) (Fig. 1).

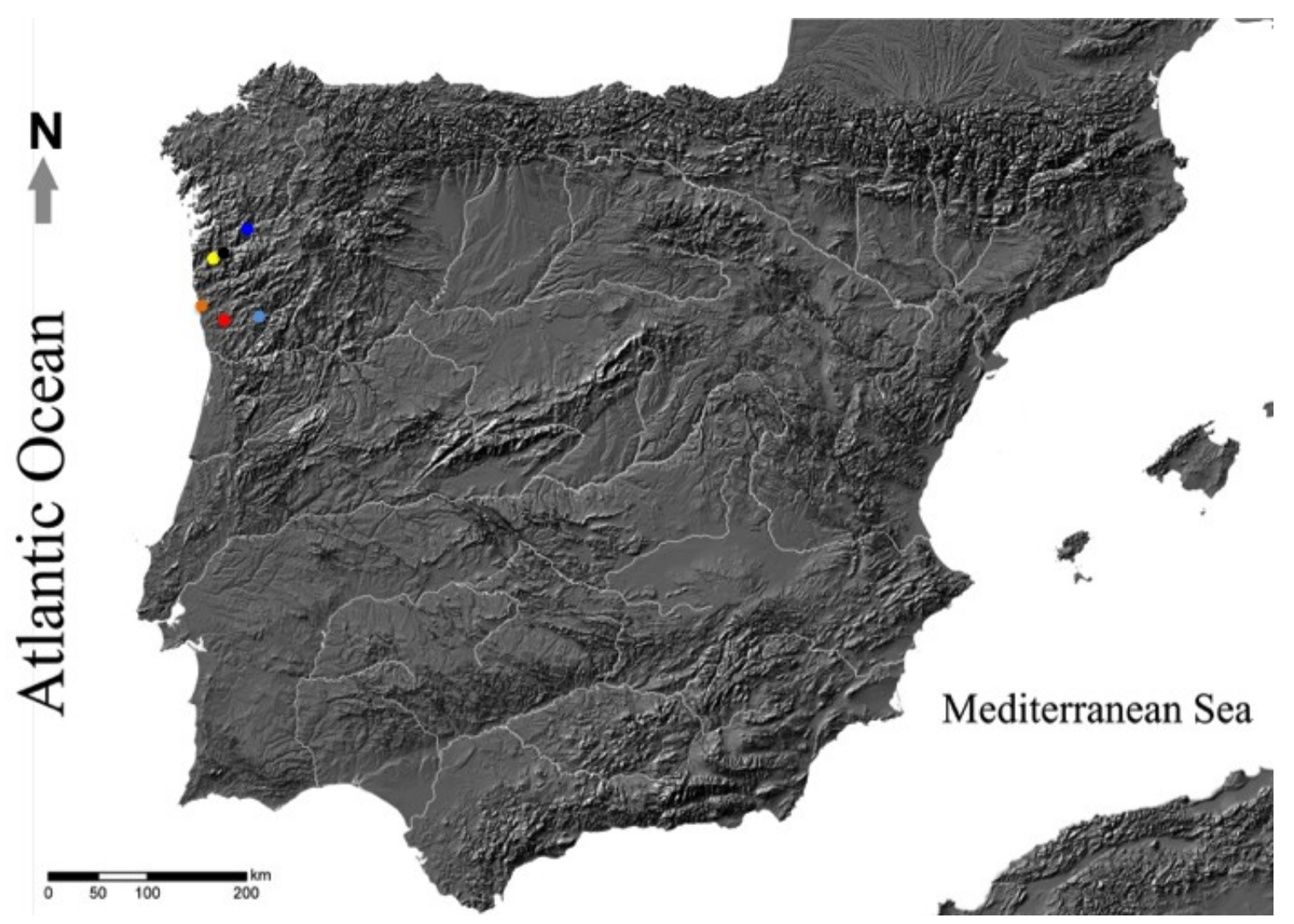

Fig. 1. The location of the hoards mentioned in the text: Senhora Aparecida/Pinheiro (light blue), Abelheira/S. Martinho do Bougado (red); Cobidalto (orange), Carpinteira/S. Paio (yellow), Ganfei/Gingleta (black) and Cabeiras (dark blue).

Fig. 1. Localização dos depósitos mencionados ao longo do texto: Senhora Aparecida/Pinheiro (azul claro), Abelheira/S. Martinho do Bougado (vermelho), Cobidalto (laranja), Carpinteira/S. Paio (amarelo), Ganfei/Gingleta (preto), Cabeiras (azul escuro).

The morphological study contemplated independent analysis of the formal and dimensional features of these axes. Such purpose was achieved either by observation of certain objects or by consulting references that included them (SARMENTO 1888, 1999; FORTES 1905-1908a, 1905-1908b; MONTEAGUDO 1977; BOTTAINI 2012; COMENDADOR REY et al. 2014; CARBALLO ARCEO \& REY CASTIÑEIRA 2014).

Whenever possible, technical study was based on published chemical composition results (SIRET 1913; BOTTAINI 2012). However, it has to be highlighted that these chemical analysis results derived from using distinct methodologies. This has to do with distinct moments when these works were conducted, since both are separated by almost hundred years. So, besides differences between methods in respect to sample collecting, the area of the objects from where these samples were collected is equally important, since some can provide higher quantities of certain components rather than others. Since this situation can provide mismatches, no inter-set comparison exercise in relation to chemical analysis was conducted. However, and even recognizing those limitations, these analyses show distinct compositions per set and the use of different alloys, specifically concerning to binary or ternary alloys.

Finally, spatial contextualization of the hoards took into account the geomorphological positioning of depositional areas, such like stranding zones or fluvial plains. Special attention was also given to some physical features, like immediate presence of water, natural circulation pathways or primary and secondary mining resources.

The major limitation of this work was the unequal nature of the data that resulted from the loss of some objects and/or the absence of information. In addition, the dispersion of some objects by different institutions and private collections precluded a more comprehensive analysis. Specifically such situations prevented us to observe personally some of the mentioned objects. 


\section{THEORETICAL BACKGROUND}

Theoretically speaking, different concepts were used.

Landscape is the dialectic result between human agency's interaction and the physical scenario where man lives (INGOLD 2000). As complex and dynamic concept, it can also be experiences and perceptions that human groups have and construct from surrounding world.

As a deposit - also commonly referred as "hoard" - we consider all intentional actions of amortization of the objects, whether in a microcontext (an outcrop, a crack or a water source) or a wider context (a geomorphological accident or a valley). Although most of times apparently decontextualized, deposition can be part of a phenomenon that characterizes different regional areas of the European Bronze Age over hundreds of years (FONTIJN 2001/2002). Although reproduced in quite different ways, such practices seem to denounce an extreme regularity among communities regionally distinct. This is particularly significant, since it may reflect a proper cosmological universe conceived by the Bronze Age communities that culminated in the act of depositing metal objects. Ultimately, a deposit is the utmost stage of a more complex process in which objects were involved, and does not necessarily means their end or 'death'. By the contrary, it must be understood as a new stage in the biography of these objects.

Following the previous idea, we must also direct our attention to the biography of objects. This concept need to be understood as a whole, since objects caught in cultural contexts achieve different meanings that surpass their simple functionality (KOPYTOFF 1986). Thus, it is assumed that objects gain their own "life" and are culturally transformed into symbols (APPADURAI 1986, GELL 1998, GOSDEN \& MARSHALL 1999, HODDER 2012), carrying significations, messages and senses. For that reason, they can also be seen as social actors (GELL 1998). Unfortunately, such "invisible" features of objects contrast with their supposed "original function", and it is not easy to reconstruct the actor intention beyond the performed depositional contexts. Here lays the real issue to deal with when studying depositional practices' phenomena.

In its existence in world man recreates and embodies different places. By knowing, experiencing and practicing them man also increases its social integration and promotes what Feld \& Basso (1996) called "sense of place". Defined by Thomas (2001: 173) as “revealed through people's habitual activities and interactions, through the closeness and affinity that they have developed for some locations (...) causing them to be remembered or incorporated into stories", a place is also something relational, rather than a simple entity. In fact, loci acquire our attention because of something that happened or by things one expects to found there. As so, people are connected within a network of places where develop a habitual and discrete familiarity, forming some kind of communion (THOMAS 2001).

Finally, and in accordance with many authors (SAHLINS 1972; DESCOLA 1996; BRADLEY 2000; THOMAS 2001; TILLEY 2004; CASTRO 2004; INGOLD 2006), we assume that for some human groups world was animated. As such, and due to parity relations established between humans and nature, it can be considered that during the Late Prehistory communities experienced, conceived and explained some phenomenon appealing to animistic and supernatural powers.

\section{DATA}

The hoard of Abelheira/S. Martinho do Bougado originally included 34 palstave axes with two rings, all of which preserving casting cones (SARMENTO 1888) (Fig. 2).

The dimensional and formal features of 29 axes $^{1}$, currently kept at Martins Sarmento Society Museum, in Guimarães, were synthesized in Table 1. Chemical analyses are equally available for 7 axes (Tab. 2).

Considering the dimensions we observed different objects varying between 19,2 to $26 \mathrm{~cm}$ of length and 2,6 to $4,3 \mathrm{~cm}$ of thickness, weighing from 784 to 1296 grams. In turn, available chemical analyses from 8 axes revealed varying levels of $\mathrm{Cu}(7,18$ to $63,32 \%), \mathrm{Sn}(2,83$ to $11,01 \%), \mathrm{Pb}$ $(24,73$ to $98,37 \%)$ and $\mathrm{Sb}(0,2$ to $2,5 \%)$. It should be noted that 3 axes also reveal high quantities of lead. However, these values correspond to samples collected directly from axe's casting cone, certainly corresponding to lead segregation.

The context of deposition (SARMENTO 1888, 1999) was described as a pit covered with a slab. The finding took place during the cleaning of a portion of lean and rough terrain, between two little elevations - a natural crossing zone (in Portuguese called "portela") developed from South to North. The geomorphological contextualization of this find corresponds to the right margin of a brook tributary of river Ave, which flows from East to West at about 1,5 to $2 \mathrm{~km}$ to North (Fig. 3).

${ }^{1}$ It was our option not to study 5 axes due to their state of preservation. Even using gloves, manipulation of those objects would certainly increase their advanced degradation. 

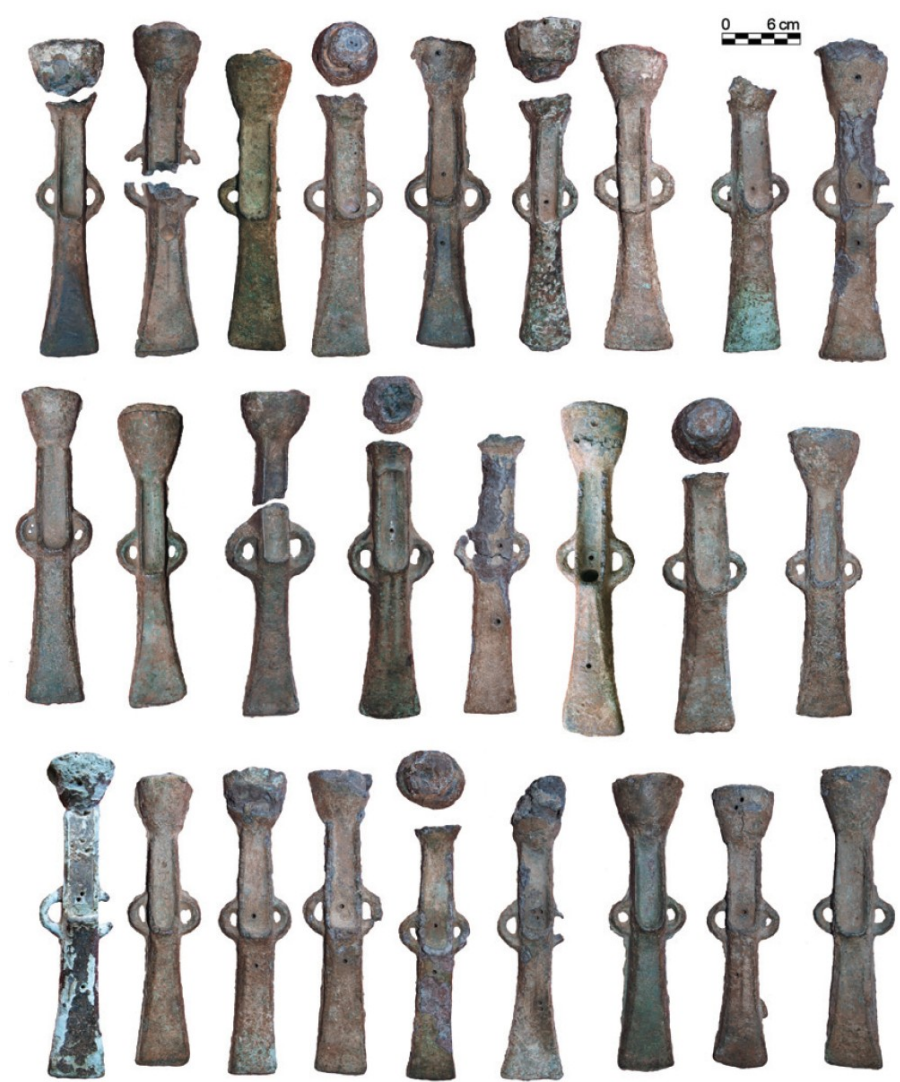

$\stackrel{0}{-6 \mathrm{~cm}}$

Fig. 2. Palstave axes with two rings and casting cones from the hoard of Abelheira/S. Martinho do Bougado, Trofa (according to BOTTAINI 2012: 374).

Fig. 2. Machados de talão de duas argolas com cones de fundição do depósito da Abelheira/S. Martinho do Bougado, Trofa (segundo BOTTAINI 2012: 374).

Tab. 1. Main characteristics of palstave axes from the hoard of Abelheira/S. Martinho do Bougado. Tab. 1. Caraterísticas principais dos machados de talão do depósito da Abelheira/S. Martinho do Bougado.

\begin{tabular}{|c|c|c|c|c|c|c|}
\hline & \multicolumn{2}{|c|}{$\begin{array}{l}\text { Dimensions } \\
\text { (cm) }\end{array}$} & \multirow{2}{*}{ Rib } & \multirow{2}{*}{$\begin{array}{l}\text { Cast. } \\
\text { cone }\end{array}$} & \multirow{2}{*}{$\begin{array}{l}\text { Weight } \\
\text { (g) }\end{array}$} & \multirow[t]{2}{*}{ Reference } \\
\hline & Length & Thickn. & & & & \\
\hline MSA-807 & 21 & 3,9 & $\mathrm{Y}$ & $\mathrm{Y}$ & 1139 & - \\
\hline MSA- 809 & 21,2 & 3,1 & $\mathrm{Y}$ & $\mathrm{Y}$ & 784 & - \\
\hline MSA- 810 & 26 & 3,6 & $\mathrm{~N}$ & $\mathrm{Y}$ & 1275 & - \\
\hline MSA-811 & 23,8 & 2,7 & $\mathrm{Y}$ & $\mathrm{Y}$ & 1031 & - \\
\hline MSA-812 & 24 & 3,3 & $\mathrm{Y}$ & $\mathrm{Y}$ & 1228 & - \\
\hline MSA-813 & 25,2 & 4 & $\mathrm{~N}$ & $\mathrm{Y}$ & 1103 & - \\
\hline MSA-814 & 22,8 & 3,3 & $\mathrm{Y}$ & $\mathrm{Y}$ & 1191 & - \\
\hline MSA-815 & 23,7 & 3,9 & $\mathrm{~N}$ & $\mathrm{Y}$ & 1193 & - \\
\hline MSA- 816 & 22,7 & 3,4 & $\mathrm{~N}$ & $\mathrm{Y}$ & 1261 & - \\
\hline MSA- 817 & 23,3 & 3,5 & $\mathrm{Y}$ & $\mathrm{Y}$ & 1227 & - \\
\hline MSA- 818 & 23,5 & 3 & $\mathrm{~N}$ & $\mathrm{Y}$ & 1254 & - \\
\hline MSA-819 & 22,8 & 3,7 & $\mathrm{~N}$ & $\mathrm{Y}$ & 1194 & - \\
\hline MSA- 820 & 23,2 & 3,5 & $\mathrm{~N}$ & $\mathrm{Y}$ & 1161 & - \\
\hline MSA- 821 & 23,3 & 3,6 & $\mathrm{~N}$ & $\mathrm{Y}$ & 1173 & - \\
\hline MSA- 822 & 19,2 & 3,7 & $\mathrm{~N}$ & $\mathrm{Y}$ & 1186 & - \\
\hline MSA- 823 & 21,7 & 2,6 & $\mathrm{~N}$ & $\mathrm{Y}$ & 809 & - \\
\hline MSA- 824 & 25,2 & 3,6 & $\mathrm{~N}$ & $\mathrm{Y}$ & 1296 & - \\
\hline MSA- 825 & 22,7 & 3,3 & $\mathrm{~N}$ & $\mathrm{Y}$ & 1157 & - \\
\hline MSA- 826 & 24,1 & 4,3 & $\mathrm{~N}$ & $\mathrm{Y}$ & 1260 & - \\
\hline MSA- 827 & 24,1 & 4 & $\mathrm{~N}$ & $\mathrm{Y}$ & 1260 & - \\
\hline MSA- 828 & 23 & 3,8 & $\mathrm{~N}$ & $\mathrm{Y}$ & 1235 & - \\
\hline MSA- 829 & 23,4 & 3,5 & $\mathrm{Y}$ & $\mathrm{Y}$ & 1280 & - \\
\hline MSA- 830 & 24,9 & 3,8 & $\mathrm{~N}$ & $\mathrm{Y}$ & 1243 & - \\
\hline MSA-831 & 20,5 & 3,2 & $\mathrm{~N}$ & $\mathrm{Y}$ & 1220 & - \\
\hline MSA- 832 & 23,2 & 3,2 & $\mathrm{~N}$ & $\mathrm{Y}$ & 1088 & - \\
\hline MSA-833 & 21 & 3,5 & $\mathrm{~N}$ & $\mathrm{Y}$ & 1203 & - \\
\hline MSA-834 & 23,8 & 3 & $\mathrm{Y}$ & $\mathrm{Y}$ & 1084 & - \\
\hline$?$ & $?$ & $?$ & $?$ & $?$ & $?$ & BOTTAINI (2012) \\
\hline
\end{tabular}


Late Bronze Age monotypological deposits of palstave axes between the hydrographic basins of rivers Minho and Ave (Iberian Northwest): spatial contexts and interpretations

Tab. 2. Chemical composition of 7 palstave axes from the hoard of Abelheira/S. Martinho do Bougado. Tab. 2. Composição química dos 7 machados de talão do depósito da Abelheira/S. Martinho do Bougado.

\begin{tabular}{|c|c|c|c|c|c|}
\hline \multirow{2}{*}{ Inv. Nr. } & \multicolumn{4}{|c|}{$\begin{array}{c}\text { Chemical composition } \\
(\%)\end{array}$} & \multirow[t]{2}{*}{ Reference } \\
\hline & $\mathrm{Cu}$ & Sn & $\mathbf{P b}$ & Sb & \\
\hline Abelheira 1a & 59,32 & 9,67 & 28,13 & 2,5 & SIRET (1913) \\
\hline Abelheira 1b & - & - & 97 & - & SIRET (1913) \\
\hline Abelheira 2 & 63,32 & 7,98 & 24,73 & 1,25 & SIRET (1913) \\
\hline Abelheira 3a & 56,05 & 5,34 & 33,6 & 1,67 & SIRET (1913) \\
\hline Abelheira 3b & 25,72 & 2,83 & 67,83 & 1,25 & SIRET (1913) \\
\hline Abelheira 4a & 51,7 & 8,1 & 40,02 & 0,75 & SIRET (1913) \\
\hline Abelheira 4b & - & - & 96 & - & SIRET (1913) \\
\hline Abelheira 5a & 50,62 & 11,01 & 26,29 & 1,83 & SIRET (1913) \\
\hline Abelheira $5 b$ & 38,05 & 10,07 & 51,12 & 0,2 & SIRET (1913) \\
\hline Abelheira 5c & - & - & 97,35 & - & SIRET (1913) \\
\hline Abelheira 6 & 7,18 & - & 84,18 & 0,94 & SIRET (1913) \\
\hline Abelheira 7a & 50,06 & 3,3 & 35,44 & 1 & SIRET (1913) \\
\hline Abelheira $7 \mathrm{~b}$ & - & - & 98,37 & - & SIRET (1913) \\
\hline$?$ & 61,48 & 8,65 & 25,75 & 0,39 & BOTTAINI (2012) \\
\hline
\end{tabular}

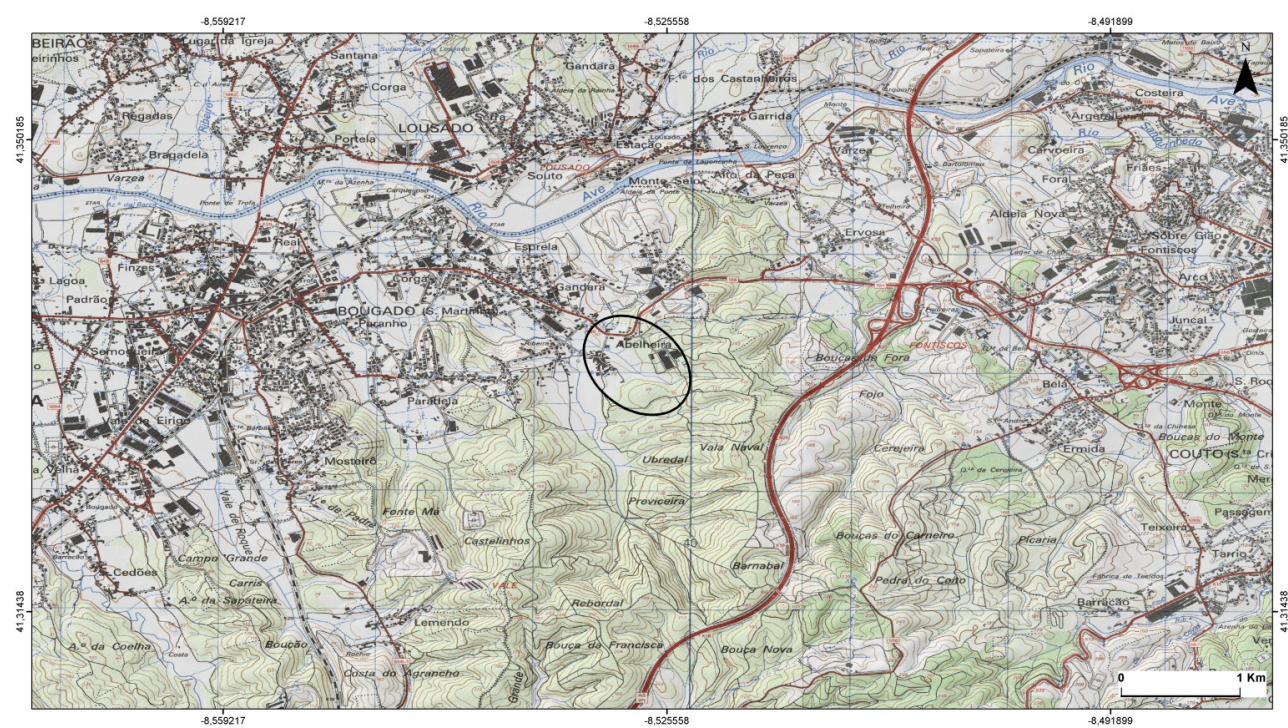

Fig. 3. Portuguese Military Chart excerpt with 3D modeling, sheet nr. 97, at 1/25 000 scale, with approximate localization of the hoard of Abelheira/S. Martinho do Bougado, Trofa (Filipe Pereira).

Fig. 3. Excerto de Carta Militar com modelado 3D, folha $\mathrm{n}^{\circ}$ 97, à escala $1 / 25$ 000, com a localização aproximada do depósito da Abelheira/S. Martinho do Bougado, Trofa (Filipe Pereira).

The hoard of Pinheiro/Senhora Aparecida originally included 6 palstave axes with two rings and casting cone (MONTEAGUDO 1977) (Fig. 4).

From the observation of available axes it stands out its heterogeneity in relation to dimen- sions and forms. Their main features, along with chemical analysis done to the axes kept in D. Diogo de Sousa Museum, in Braga, were synthesized in Table 3. It is worth noting the chemical differences between each axe.

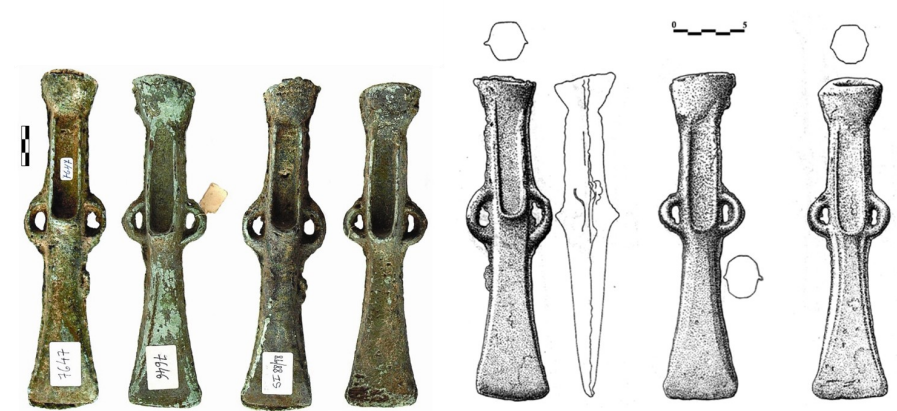

Fig. 4. At left, axes from the hoard of Pinheiro/Senhora Aparecida kept in the D. Diogo de Sousa Museum, in Braga (author: Manuel Santos); right, axes represented by Monteagudo (1977).

Fig. 4. À esquerda, machados do depósito de Pinheiro/Senhora Aparecida guardados no Museu D. Diogo de Sousa, em Braga (autor: Manuel Santos); à direita, machados representados por Monteagudo (1977). 
From the 4 objects available for observation we highlight their formal and dimensional heterogeneity (Tab. 3). The dimensions of the set vary between 21,5 to $24,4 \mathrm{~cm}$ of length and 2,4 to 2,8 $\mathrm{cm}$ of thickness, weighing from 1204 to 1374 grams. In relation to their chemical composition there were varying levels of $\mathrm{Cu}(\approx 66$ to $74 \%), \mathrm{Sn}$ $(\approx 3,1$ to $18 \%)$ and $\mathrm{Pb}(8,4$ to $\approx 31 \%)$. The vestigial presence of $\mathrm{Ni}(0,1 \%)$ was found in two objects.

As described by Pinto (1995: 270, footnote 6) the hoard was found when a worker dragged a root of a tree in the southwest slope of Mount of Aparecida. Based on this, we can geomorphologically contextualize the discovery in a hillside, which is almost immediate to a considerable dynamic fluvial watercourse called Passarias (Fig. 5)

Tab. 3. Main characteristics of Pinheiro/Senhora Aparecida's palstave axes.

Tab. 3. Caraterísticas principais dos machados de talão de Pinheiro/Senhora Aparecida.

\begin{tabular}{|c|c|c|c|c|c|c|c|c|c|c|}
\hline \multirow{2}{*}{ Inv. Nr. } & \multicolumn{4}{|c|}{$\begin{array}{c}\text { Chemical composition } \\
(\%)\end{array}$} & \multicolumn{2}{|c|}{$\begin{array}{l}\text { Dimensions } \\
\text { (cm) }\end{array}$} & \multirow{2}{*}{ Rib } & \multirow{2}{*}{$\begin{array}{l}\text { Coast. } \\
\text { cone }\end{array}$} & \multirow{2}{*}{ Weight (g) } & \multirow{2}{*}{ References } \\
\hline & $\mathbf{C u}$ & Sn & $\mathbf{P b}$ & $\mathbf{N i}$ & Length & Thickn. & & & & \\
\hline 2010.0064 & $\approx 66$ & $\approx 3,1$ & $\approx 31$ & - & 23,4 & 2,4 & $\mathrm{~N}$ & $\mathrm{Y}$ & 1245 & BOTTAINI (2012) \\
\hline 2010.0065 & 74 & 18 & 8,4 & - & 23,8 & 2,6 & $\mathrm{~N}$ & $\mathrm{Y}$ & 1204 & BOTTAINI (2012) \\
\hline 2010.0066 & 72 & 4,6 & 23 & 0,1 & 24,4 & 2,6 & $\mathrm{~N}$ & $\mathrm{Y}$ & 1374 & BOTTAINI (2012) \\
\hline 2010.0088 & 70 & 8 & 22 & 0,1 & 21,5 & 2,8 & $\mathrm{~N}$ & $\mathrm{Y}$ & 1280 & BOTTAINI (2012) \\
\hline
\end{tabular}

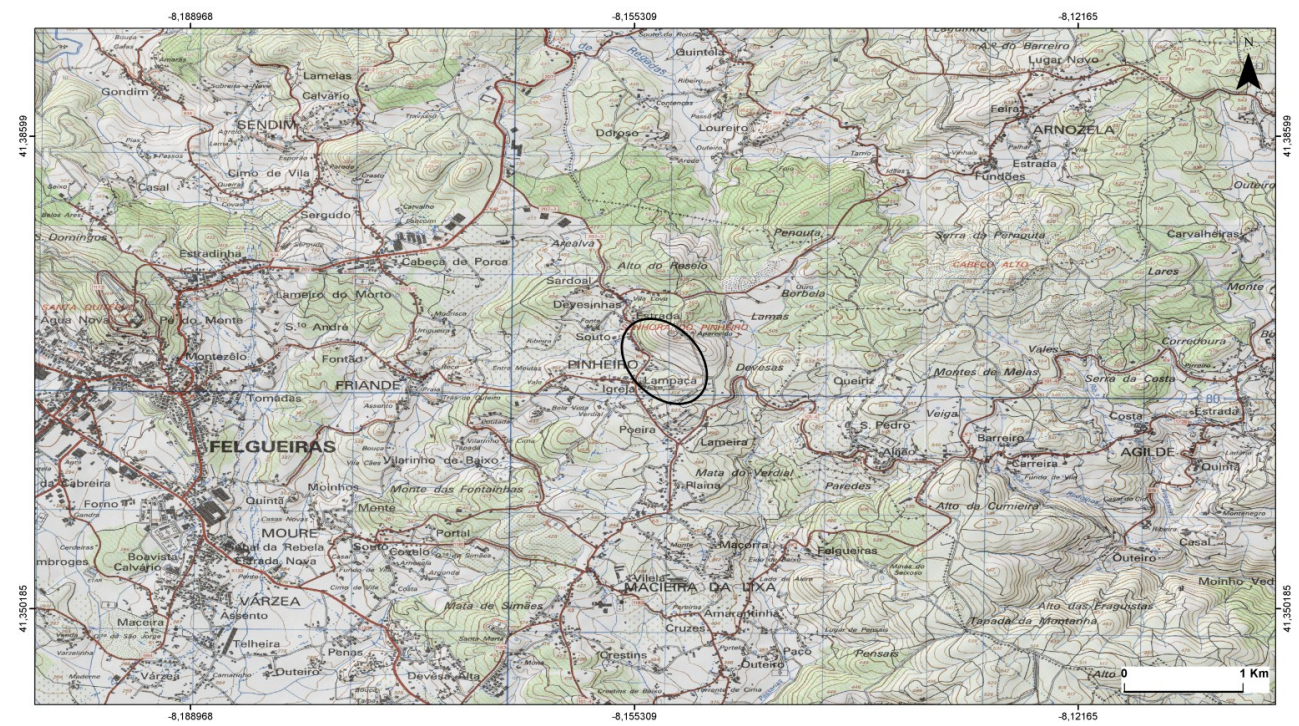

Fig. 5. Portuguese Military Chart excerpt with 3D modeling, sheet nr. 99, at 1/25 000 scale, with the approximate localization of the hoard of Pinheiro/Senhora Aparecida, Felgueiras (Filipe Pereira).

Fig. 5. Excerto de Carta Militar com modelado 3D, folha $n^{\circ} 99$, à escala 1/25 000, com a localização aproximada do depósito de Pinheiro/Senhora Aparecida (Filipe Pereira).

The hoard of Cobidalto included 8 palstave axes with two rings (MONTEAGUDO 1977). Excepting one axe, all the remaining preserved the casting cone and no signs of use were detected (BETTENCOURT et al. 2014) (Fig. 6). The dimensional and formal features of objects were synthesized in Table 4.

Considering both data from Monteagudo (1977) and from Bettencourt et al. (2014) we observed that both dimensionally and formally objects are distinct, varying between 21,3 to $27 \mathrm{~cm}$ of length and 2,4 to $4,5 \mathrm{~cm}$ of thickness, and weighing from $\approx 1025$ to $\approx 1225$ grams (Tab. 4). There were no chemical analyses available.

According to recent relocation of this hoard (BETTENCOURT et al. 2014), the axes were found inside a natural wedge-shaped cavity, roughly NorthSouth orientated, measuring about $1 \mathrm{~m}$ length, $40 \mathrm{~cm}$ width and $30 \mathrm{~cm}$ depth. Although its current location is about 1,5 m to North form brook of Fincão, the original course was slightly deflected (Fig. 7). One or two axes were uncovered, along with some dirt and pebbles, and the remaining 6 or 7 were positioned beneath them. This location is positioned in a natural corridor linking continental lands with Atlantic coastline, and is also part of the Atlantic platform, developed from South to North.

The hoard of Carpinteira/S. Paio included 6 palstave axes with two rings, two of which still preserving casting cone (FORTES 1905-1908a) (Fig. 8). The brief description of Fortes (1905-1908a) shows both dimensional and formal differences within the set. Unfortunately, recent chemical analysis made to 3 objects (BOTTAINI 2012) currently kept in D. Diogo de Sousa Museum, at Braga, did not allowed any match with the described objects by Fortes (19051908a). Yet, the results corroborate variations in their compositions (Tab. 5). 


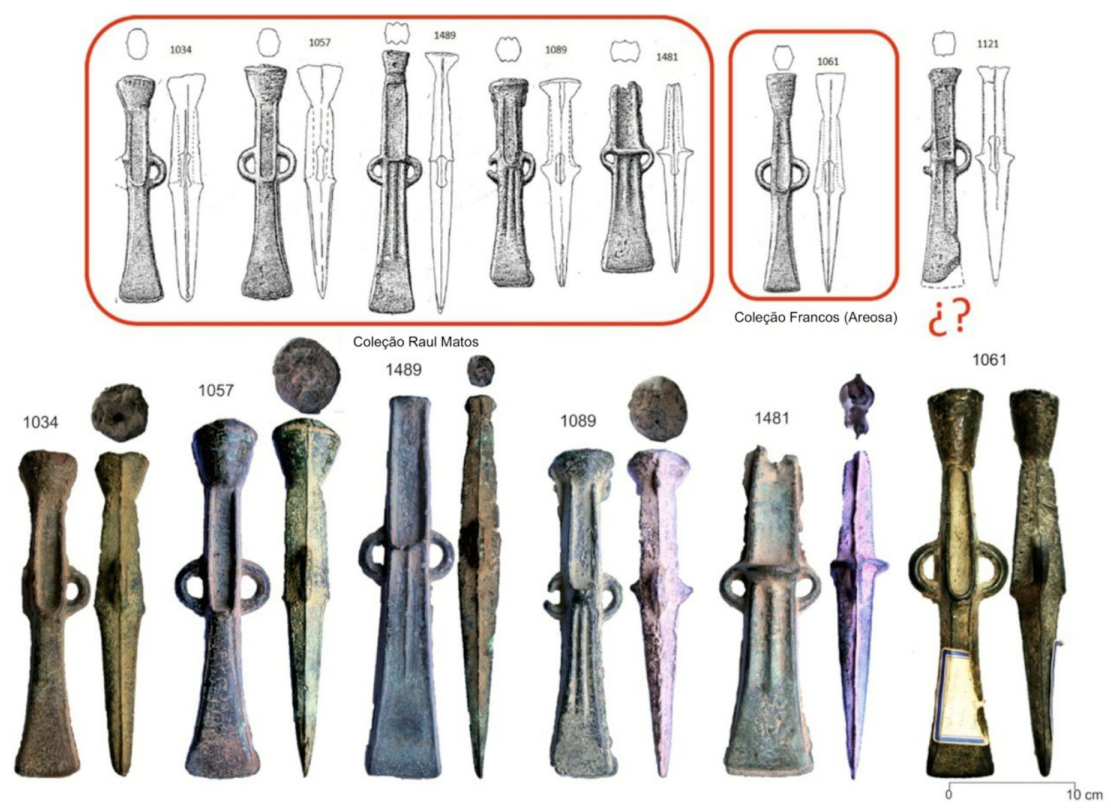

Fig. 6. Palstave axes from the hoard of Cobidalto, Areosa (according to BETTENCOURT et al. 2014: 137). Fig. 6. Machados de talão do depósito de Cobidalto, Areosa (segundo BETTENCOURT et al. 2014: 137).

Tab. 4. Main characteristics of the axes from the hoard of Cobidalto, Areosa. Tab. 4. Caraterísticas principais dos machados do depósito de Cobidalto, Areosa.

\begin{tabular}{|c|c|c|c|c|c|c|}
\hline \multirow{2}{*}{ Inv. Nr. } & \multicolumn{2}{|c|}{ Dimensions } & \multirow{2}{*}{ Rib } & \multirow{2}{*}{$\begin{array}{l}\text { Cast. } \\
\text { cone }\end{array}$} & \multirow{2}{*}{$\begin{array}{c}\text { Weight } \\
\text { (g) }\end{array}$} & \multirow{2}{*}{ References } \\
\hline & Lenght & Thickn. & & & & \\
\hline 1034 & 23,7 & 3,7 & $\mathrm{~N}$ & $\mathrm{Y}$ & $\approx 1200$ & MONTEAGUDO (1977) \\
\hline 1057 & 24,4 & 3 & $\mathrm{~N}$ & $\mathrm{Y}$ & $\approx 1100$ & MONTEAGUDO (1977) \\
\hline 1111 & 27 & 3 & $\overline{\mathrm{Y}}$ & $\overline{\mathrm{Y}}$ & $\approx 1225$ & MONTEAGUDO (1977) \\
\hline 1089 & 23 & 4,5 & $\mathrm{Y}$ & $\mathrm{Y}$ & $\approx 1075$ & MONTEAGUDO (1977) \\
\hline 1481 & 21,7 & 4,3 & $\mathrm{Y}$ & $\mathrm{Y}$ & $\approx 1025$ & MONTEAGUDO (1977) \\
\hline 1061 & 21,3 & 3,9 & $\mathrm{~N}$ & $\overline{\mathrm{Y}}$ & $\approx 1172$ & MONTEAGUDO (1977) \\
\hline 1489 & 25 & 2,4 & $\mathrm{Y}$ & $\mathrm{N}$ & - & MONTEAGUDO (1977) \\
\hline 1121 & 21,4 & 2,8 & $\overline{\mathrm{Y}}$ & $\mathrm{Y}$ & - & MONTEAGUDO (1977) \\
\hline
\end{tabular}

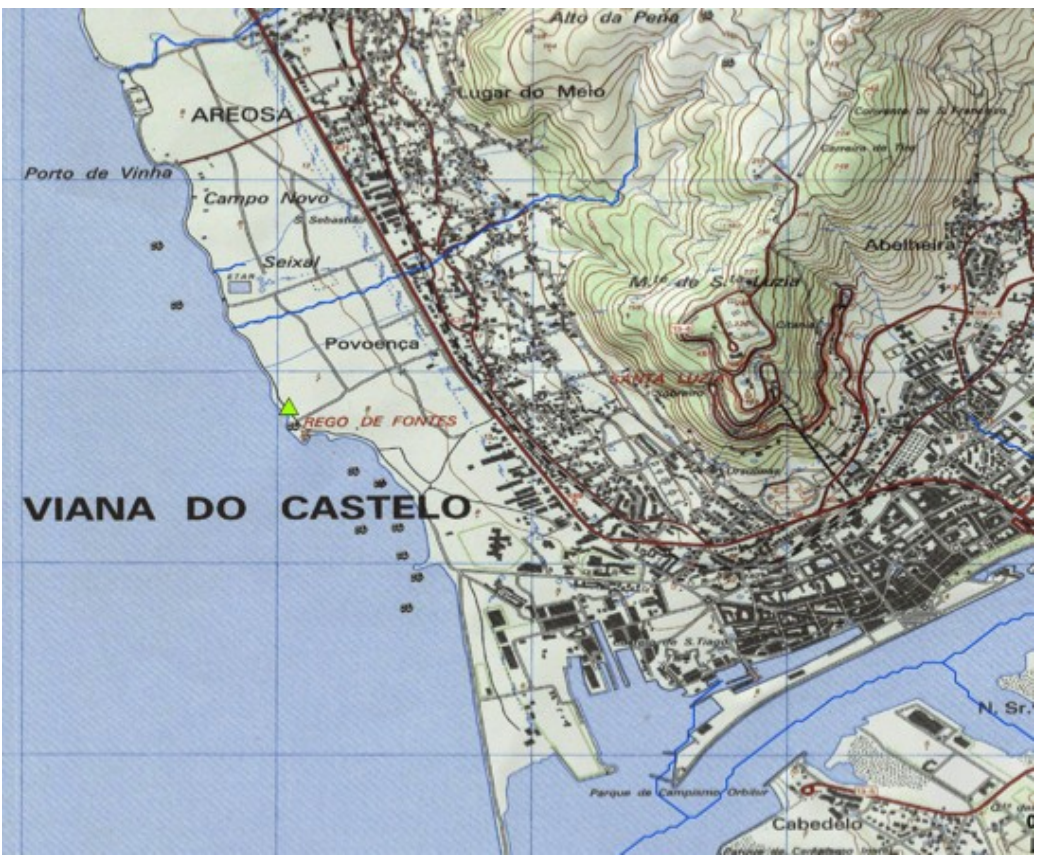

Fig. 7. Portuguese Military Chart excerpt with 3D modeling, sheet nr. 40, at 1/25 000 scale, with approximate localization of the hoard of Cobidalto, Viana do Castelo (BETTENCOURT et al. 2014: 136).

Fig. 7. Excerto de Carta Militar com modelado 3D, folha n ${ }^{\circ} 40$, à escala 1/25 000, com a localização aproximada do depósito de Cobidalto, Viana do Castelo (BETTENCOURT et al. 2014: 136). 


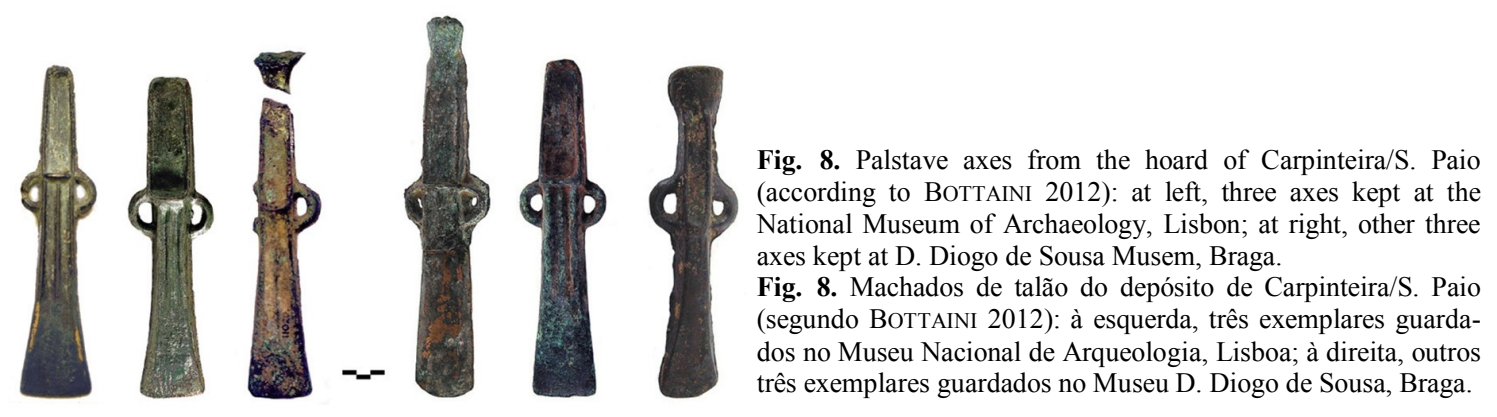

Tab. 5. Main characteristics of the axes from the hoard of Carpinteira/S. Paio.

Tab. 5. Caraterísticas principais dos machados do depósito de Carpinteira/S. Paio.

\begin{tabular}{|c|c|c|c|c|c|c|c|c|c|}
\hline \multirow{2}{*}{ Inv. Nr. } & \multicolumn{3}{|c|}{$\begin{array}{c}\text { Chemical composition } \\
\text { (\%) }\end{array}$} & \multicolumn{2}{|c|}{$\begin{array}{l}\text { Dimensions } \\
\text { (cm) }\end{array}$} & \multirow{2}{*}{ Rib } & \multirow{2}{*}{$\begin{array}{l}\text { Cast. } \\
\text { cone }\end{array}$} & \multirow{2}{*}{$\begin{array}{l}\text { Weight } \\
\text { (g) }\end{array}$} & \multirow{2}{*}{ References } \\
\hline & $\mathrm{Cu}$ & Sn & $\mathbf{P b}$ & Lenght & Thickn. & & & & \\
\hline 1 & - & - & - & 25,3 & 4 & $?$ & $\mathrm{~N}$ & 1490 & FORTES (1905-1908a) \\
\hline 2 & - & - & - & 24,2 & 3,5 & $?$ & $\mathrm{~N}$ & 1100 & FORTES (1905-1908a) \\
\hline 3 & - & - & - & 24,5 & 4,5 & $?$ & $\mathrm{Y}$ & 1950 & FORTES (1905-1908a) \\
\hline 4 & - & - & - & 27,3 & 4 & $?$ & $\mathrm{Y}$ & 1167 & FORTES (1905-1908a) \\
\hline 5 & - & - & - & 24,2 & 4,5 & $?$ & $\mathrm{~N}$ & 1087 & FORTES (1905-1908a) \\
\hline 2010.0071 & 76,9 & 20,3 & 2,76 & 24,5 & 2,9 & $\mathrm{Y}$ & $\mathrm{N}$ & 1113 & BOTTAINI (2012) \\
\hline 2010.0080 & 71,5 & 8,16 & 20,3 & 23,1 & 3,1 & $\mathrm{~N}$ & $\bar{Y}$ & 1181 & BoTTAINI (2012) \\
\hline 2010.0087 & 78,8 & 16 & 5,2 & 26,3 & 3,2 & $\mathrm{~N}$ & $\mathrm{Y}$ & 1165 & BOTTAINI (2012) \\
\hline
\end{tabular}

Considering the description by Fortes (19051908a) one can verify that objects vary between 24,2 to $27,3 \mathrm{~cm}$ of length and 3,5 to $4,5 \mathrm{~cm}$ of thickness, weighing from 1087 to 1950 grams. In relation to objects stored in D. Diogo de Sousa Museum, dimensions vary between 23,1 to $26,3 \mathrm{~cm}$ of length and 2,9 to $3,2 \mathrm{~cm}$ of thickness, weighing from 1113 to 1181 grams. The chemical analyses to these three objects revealed variable levels of $\mathrm{Cu}(71,5$ to $78,8 \%)$, Sn (8,16 to $20,3 \%)$ and $\mathrm{Pb}(2,76$ to $16 \%)$.
In spite of the lack of information about the depositional context of this hoard (FORTES 1905-1908a), it is known that it was found in a piece of unfarmed land during the extraction of a pine tree, locally known as Carpinteira, parish of S. Paio. The 6 bronze axes appeared in the roots of a tree. Its geomorphological contextualization, obviously approximate, situates this set in the base of a hillside, at about 2,5 to $3 \mathrm{~km}$ from the left margin of river Minho and very close to the brook of S. Lourenço, a tributary of that river (Fig. 9).

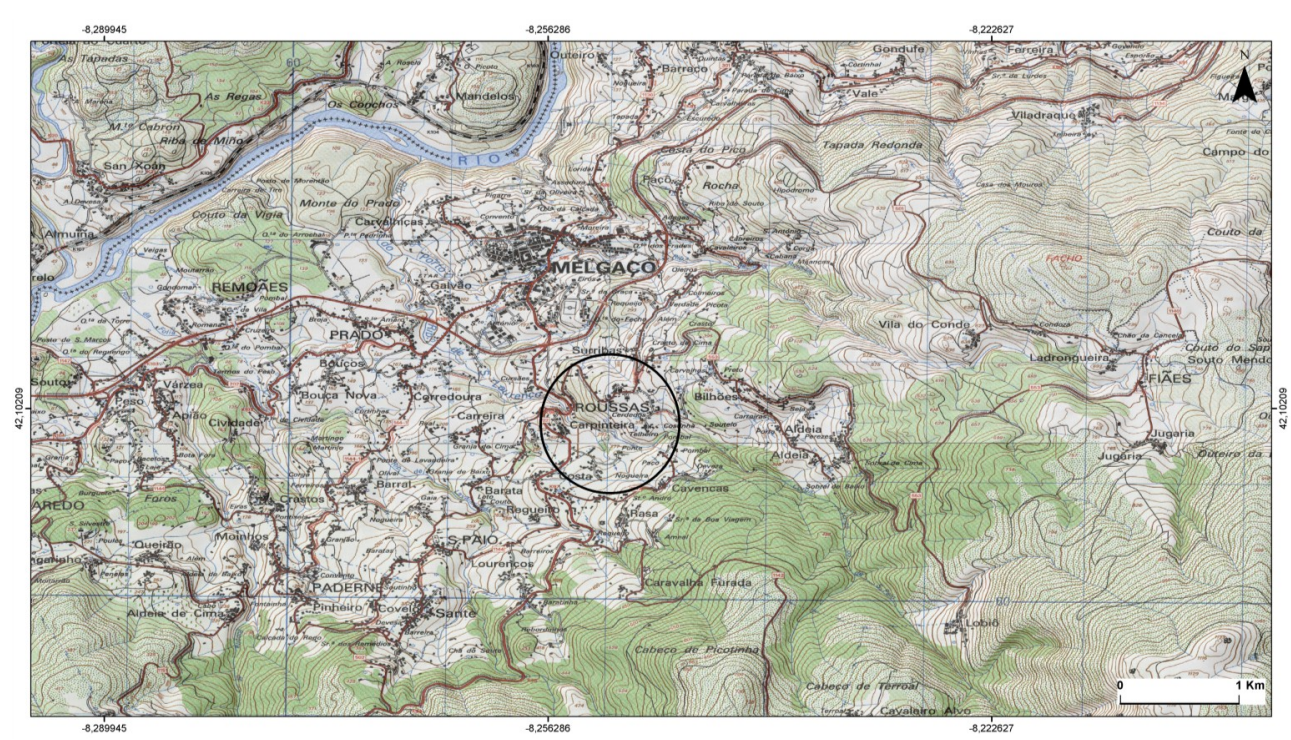

Fig. 9. Portuguese Military Chart excerpt with 3D modeling, sheet nr. 1, at 1/25 000 scale, with the approximate localization of the hoard of Carpinteira/S. Paio, Valença (Filipe Pereira).

Fig. 9. Excerto de Carta Militar com modelado $3 \mathrm{D}$, folha $\mathrm{n}^{\circ} 1$, à escala $1 / 25000$, com a localização aproximada do depósito de Carpinteira/S. Paio, Valença (Filipe Pereira). 
The hoard of Gingleta/Ganfei included 24 palstave axes. Although later separated, Fortes (1905-1908b) recovered and described 15 of them, from which 5 were broken.

According to that author at least 8 axes included casting cones. The terms "broken ring" or "cone, two rings, broken edge" (FORTES 1905- 1908b: 661) used to describe some objects may lead us to presume that probably they were provided with one or, in some cases, two rings each. Moreover, they would be similar to the axe studied by Bottaini (2012) in relation to its chemical composition, which is kept at D. Diogo de Sousa Museum, Braga (Fig. 10).

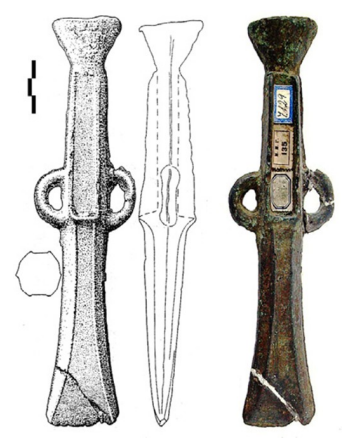

Fig. 10. The single axe from the hoard of Gingleta/Ganfei currently available at D. Diogo de Sousa Museum, Braga; at left according to Bottaini (2012), at right according to Monteagudo (1977).

Fig. 10. O único machado do depósito de Gingleta/Ganfei, atualmente disponível no Museu D. Diogo de Sousa, Braga; à esquerda segundo Bottaini (2012), à direita segundo Monteagudo (1977).

The data registered by Fortes (1905-1908b) confirms the heterogeneity of this set (Tab. 6).

Excluding 5 broken objects, it is possible to verify that the axes from this set are both dimensionally and formally distinct, varying between 22,3 to $25,5 \mathrm{~cm}$ of length and 3 to $4,3 \mathrm{~cm}$ of thickness, and weighing from 1055 to 1300 grams. Just one axe was analyzed to its chemical composition, making unfeasible any attempt to determine intraset differences. Available results showed the pres- ence of $\mathrm{Cu}(71,1 \%), \mathrm{Sn}(13,2 \%)$ and $\mathrm{Pb}(16,5 \%)$.

This set was recovered during the removal of a pine tree in a piece of unfarmed land near the police station of Gingleta, close to the left margin of river Minho (FORTES 1905-1908b). Moreover, old military cartography still preserves the toponym "Ginguelêta". Such a positioning makes this set the closest of a wide fluvial watercourse, occupying the left alluvial margin of river Minho (Fig. 11).

Tab. 6. Main characteristics of the axes from the hoard of Gingleta/Ganfei.

Tab. 6. Caraterísticas principais dos machados do depósito de Gingleta/Ganfei.

\begin{tabular}{|c|c|c|c|c|c|c|c|c|c|c|}
\hline \multirow[t]{2}{*}{ Inv. Nr. } & \multicolumn{3}{|c|}{$\begin{array}{c}\text { Chemical composition } \\
(\%)\end{array}$} & \multicolumn{2}{|c|}{$\begin{array}{c}\text { Dimensions } \\
(\mathbf{c m})\end{array}$} & \multirow[t]{2}{*}{ Rib } & \multirow{2}{*}{$\begin{array}{l}\text { Cast. } \\
\text { cone }\end{array}$} & \multirow{2}{*}{$\begin{array}{l}\text { Weight } \\
\text { (g) }\end{array}$} & \multirow[t]{2}{*}{ Broken } & \multirow[t]{2}{*}{ References } \\
\hline & $\mathrm{Cu}$ & Sn & $\mathbf{P b}$ & Length & Thickn. & & & & & \\
\hline 1 & - & - & - & 25,2 & 3,45 & & $\mathrm{~N}$ & 1225 & $\mathrm{~N}$ & FORTES (1905-1908b) \\
\hline 2 & - & - & - & 24,6 & 3,4 & & $\mathrm{Y}$ & 1185 & $\mathrm{~N}$ & FORTES (1905-1908b) \\
\hline 3 & - & - & - & 23,3 & 4,05 & & $\mathrm{Y}$ & 1215 & $\mathrm{~N}$ & FORTES (1905-1908b) \\
\hline 4 & - & - & - & 24,4 & 3 & & $\mathrm{Y}$ & 1115 & $\mathrm{~N}$ & FORTES (1905-1908b) \\
\hline 5 & - & - & - & 22,3 & 3,1 & & $\mathrm{Y}$ & 1105 & $\mathrm{~N}$ & FORTES (1905-1908b) \\
\hline 6 & - & - & - & 22,5 & 3,9 & & $\mathrm{Y}$ & 1115 & $\mathrm{~N}$ & FORTES (1905-1908b) \\
\hline 7 & - & - & - & 22,5 & 4,1 & & $\mathrm{Y}$ & 1240 & $\mathrm{~N}$ & FORTES (1905-1908b) \\
\hline 8 & - & - & - & 24,7 & 4,2 & & $\mathrm{~N}$ & 1055 & $\mathrm{~N}$ & FORTES (1905-1908b) \\
\hline 9 & - & - & - & 22,8 & 4,3 & & $\mathrm{Y}$ & 1155 & $\mathrm{~N}$ & FORTES (1905-1908b) \\
\hline 10 & - & - & - & 22,9 & 3,7 & & $\mathrm{~N}$ & 1300 & $\mathrm{~N}$ & FORTES (1905-1908b) \\
\hline 11 & - & - & - & 16,7 & 4 & & $?$ & 850 & $\mathrm{Y}$ & FORTES (1905-1908b) \\
\hline 12 & - & - & - & 12,7 & 3,4 & & $?$ & 700 & $\mathrm{Y}$ & FORTES (1905-1908b) \\
\hline 13 & - & - & - & 12,3 & 3,2 & & $?$ & 680 & $\mathrm{Y}$ & FORTES (1905-1908b) \\
\hline 14 & - & - & - & 7 & - & & $?$ & 264 & $\mathrm{Y}$ & FORTES (1905-1908b) \\
\hline 15 & & & & 6,5 & - & & $?$ & 288 & $\mathrm{Y}$ & FORTES (1905-1908b) \\
\hline 2010.0077 & 71,1 & 12,3 & 16,5 & 21,8 & 2,8 & & $\mathrm{Y}$ & 1200 & $\mathrm{~N}$ & BOTTAINI (2012) \\
\hline
\end{tabular}




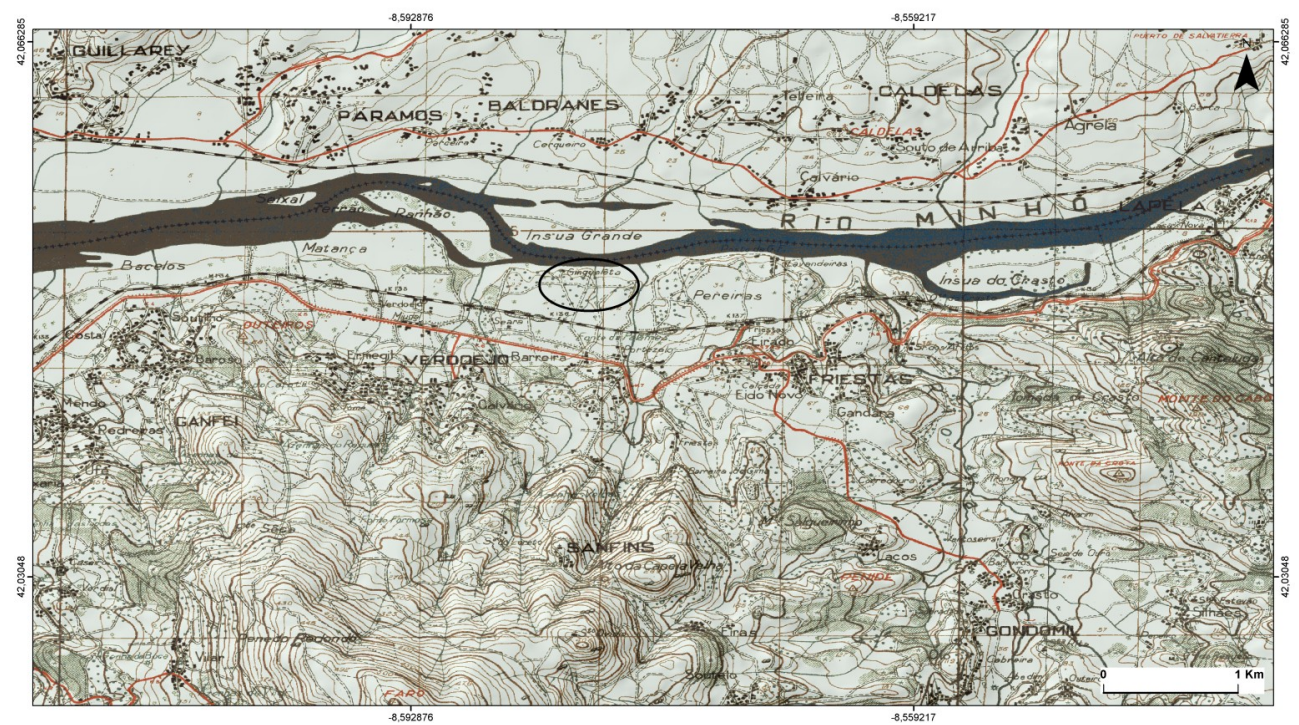

Fig. 11. Portuguese Military Chart with 3D modeling, sheet nr. 2, at 1/25 000 scale, with the approximate localization of the hoard of Gingleta/Ganfei, Valença (Filipe Pereira).

Fig. 11. Excerto de Carta Militar com modelado 3D, folha $n^{\circ} 2$, à escala $1 / 25000$, com a localização aproximada do depósito de Gingleta/Ganfei, Valença (Filipe Pereira).

Finally, the hoard of Cabeiras included 10 palstave axes with two rings and castings cones (CARBALLO ARCEO \& REY CASTIÑEIRA 2014) (Fig. 12). The dimensional and formal features were synthesized on Table 7.

Considering both data from Monteagudo
(1977) and from Carballo Arceo \& Rey Castiñeira (2014) we can verify that both dimensionally and formally objects are distinct, varying between 21,3 to $27 \mathrm{~cm}$ of length and 2,4 to $4,5 \mathrm{~cm}$ of thickness, and weighing from $\approx 1025$ to $\approx 1225$ grams. Still, there are no chemical analyses available.

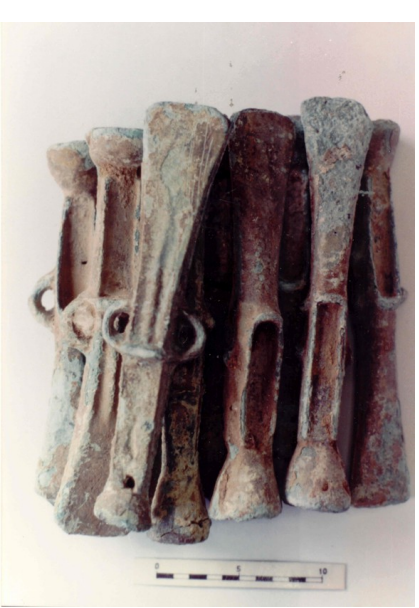

Fig. 12. Palstave axes from the hoard of Cabeiras, Arbo (CARBallo ARCEO \& Rey CASTiÑEIRA 2014: 105)

Fig. 12. Machados de talão do depósito de Cabeiras, Arbo (CARBALLO ARCEO \& REY CASTIÑEIRA 2014: 105).

Tab. 7. Main characteristics of the axes from the hoard of Cabeiras, Arbo.

Tab. 7. Caraterísticas principais dos machados do depósito de Cabeiras, Arbo.

\begin{tabular}{|c|c|c|c|c|c|l|}
\hline \multirow{2}{*}{ Inv. Nr. } & \multicolumn{2}{|c|}{$\begin{array}{c}\text { Dimensions } \\
(\mathbf{c m})\end{array}$} & \multirow{2}{*}{ Rib } & $\begin{array}{c}\text { Cast. } \\
\text { cone }\end{array}$ & $\begin{array}{c}\text { Weight } \\
\mathbf{( g )}\end{array}$ & \multicolumn{1}{|c|}{ References } \\
\cline { 2 - 5 } & Lenght & Thickn. & & & & \\
\hline 1 & 23,8 & 3,9 & $\mathrm{Y}$ & $\mathrm{Y}$ & 1035 & CARBALLO ARCEO \& REY CASTIÑEIRA (2014) \\
\hline 2 & 23,9 & 3,6 & $\mathrm{Y}$ & $\mathrm{Y}$ & 1111 & CARBALLO ARCEO \& REY CASTIÑEIRA (2014) \\
\hline 3 & 25,5 & 3,4 & $\mathrm{~N}$ & $\mathrm{Y}$ & 938 & CARBALLO ARCEO \& REY CASTIÑEIRA (2014) \\
\hline 4 & 23,9 & 4,2 & $\mathrm{~N}$ & $\mathrm{Y}$ & 1078 & CARBALLO ARCEO \& REY CASTIÑEIRA (2014) \\
\hline 5 & 23,8 & 3,6 & $\mathrm{~N}$ & $\mathrm{Y}$ & 1015 & CARBALLO ARCEO \& REY CASTIÑEIRA (2014) \\
\hline 6 & 23,2 & 3,8 & $\mathrm{~N}$ & $\mathrm{Y}$ & 1039 & CARBALLO ARCEO \& REY CASTIÑEIRA (2014) \\
\hline 7 & 22,7 & 3,4 & $\mathrm{~N}$ & $\mathrm{Y}$ & 1012 & CARBALLO ARCEO \& REY CASTIÑEIRA (2014) \\
\hline 8 & 22 & 4,2 & $\mathrm{~N}$ & $\mathrm{Y}$ & 1108 & CARBALLO ARCEO \& REY CASTIÑEIRA (2014) \\
\hline 9 & 23 & 3,4 & $\mathrm{~N}$ & $\mathrm{Y}$ & 939 & CARBALLO ARCEO \& REY CASTIÑEIRA (2014) \\
\hline 10 & 23,6 & 3,9 & $\mathrm{~N}$ & $\mathrm{Y}$ & 928 & CARBALLO ARCEO \& REY CASTIÑEIRA (2014) \\
\hline
\end{tabular}


About its depositional context, the set was found in the soil at about $80 \mathrm{~cm}$ depth, during the planting of vines (CARBALLO ARCEO \& REY CASTIÑEIRA 2014). The axes were piled together alternating their edges orientation and one axe was intentionally broken, probably due to some kind of post-depositional process (Fig. 13)

Geomorphologically the set was recovered in a hillside in the valley of river Cea, a tributary of the right margin of river Minho and to which the course flows, opening its valley from North to South.

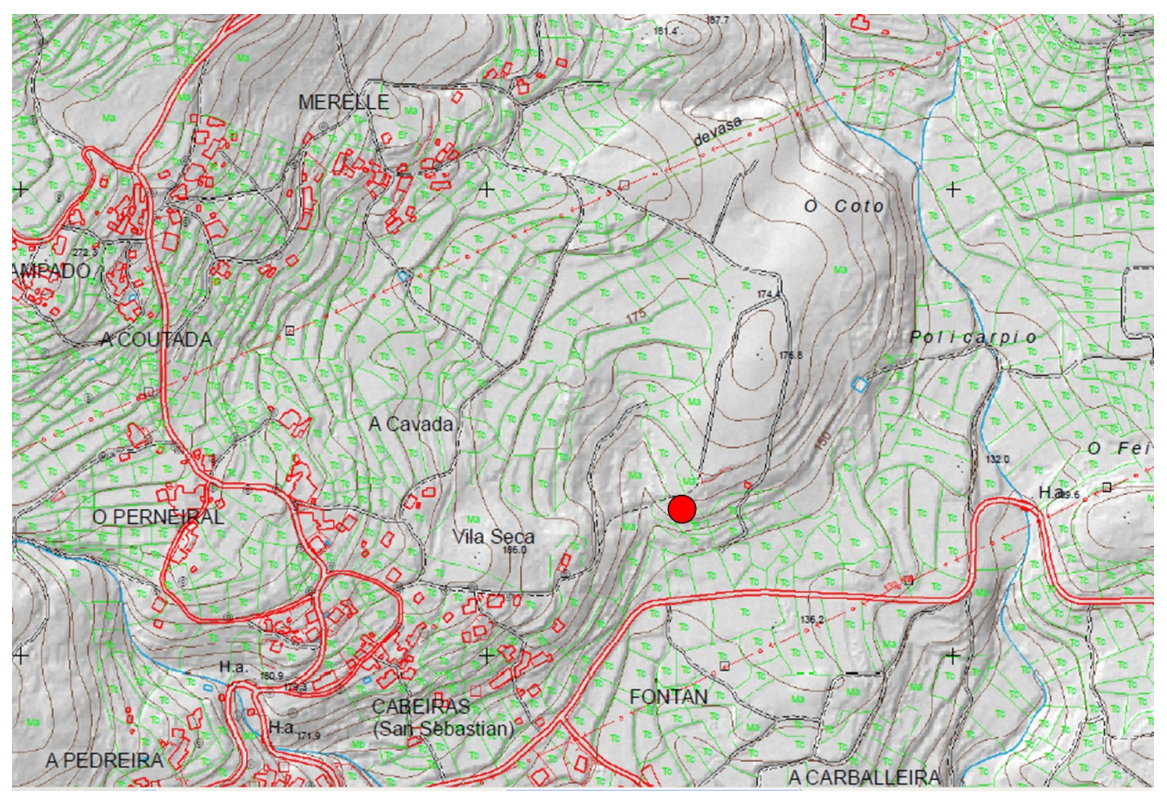

Fig. 13. Spanish Military Chart with $3 \mathrm{D}$ modeling, sheet nr. 262-II, at scale $1 / 25000$, locating the hoard of Cabeiras, Arbo (according to CARBALlO ARCEO \& REY CASTIÑEIRA 2014: 106).

Fig. 13. Excerto de Carta Militar de Espanha com modelado 3D, folha $n^{\circ} 262-$ II, à escala $1 / 25000$, com a localização do depósito de Cabeiras, Arbo (CARBALlo ARCEO \& REY CASTIÑEIRA 2014: 106).

\section{DATA DISCUSSION AND RESULTS}

The morphological and technical variations observed between axes of a same set allowed us to consider that each object is unique and individual, both in relation to its form, dimensions, weight and final finishing (or absence of it). This idea, already proposed in recent research for both the cases of Abelheira/S. Martinho do Bougado (Trofa) and Pineiro/Senhora Aparecida (Felgueiras) (SAMPAIO 2014), indicates the use of different moulds during the productive process. Even considering that we are referring to handmade productions, where integral reproduction of a same object was hard to get, we hypothesize that different objects are the result of distinct manufactures, and that probably had their origin in distinct productive loci (SAMPAIO 2014).

Although the available chemical analyses conducted by Siret (1913) have their limitations ${ }^{2}$, it is possible to say that each axe of a same deposit has its distinct chemical composition. In some sets binary bronze pieces are associated with other frankly or tenuously ternary alloys (as in the cases of Abelheira/S. Martinho do Bougado and Carpinteira/S. Paio). This may eventually indicate the use and manipulation of different alloys.

We also verified that the founding of each cited hoard did not occur in residential areas. However, to some authors it seems normal to associate these groups of objects to that kind of "domestic contexts". Transcending simple 'economic' presumption often attributed, we observe that these findings are located in the vicinities of somehow dynamic and wider watercourses (Fig. 14 and Fig. 15). Their proximity to great natural circulation pathways (like rivers basins) or passages between different hydrographic basins (like ridges), that is, in the vicinities of routes accessible from several spots, can be related with people's itineration. Thereby, the use of these itineration areas certainly promoted encounters and meetings among different communities. It can be equally questionable if many of these meetings did not result from the expressed will of some involved actors.

At the same time, the location of these hoards seems concerned with the 'observation' of opposite margins or wider segments of the 'paths' that those natural circulation routes provided.

Thus, such preoccupation could also express

${ }^{2}$ For this and other reasons we advocate some kind of specific approach to this matter, perhaps even a research project. 
an intentional willing to correlate paths, actors and objects. Concretely, emphasizing their relations and interactions, their lives and biographies, their movements and contacts.

Furthermore, and attending to Iberian Northwest general mineral richness, some of these sets were also close to watercourses containing alluvial cassiterite $(\mathrm{SnO} 2)$. This was the case of the hoards of Abelheira/S. Martinho do Bougado and Pinheiro/Senhora Aparecida. In both cases, the occupied zones were close to local rivers constantly supplied by primary tin veins from Vilarinho das Cambas/Pedras Negras (county of Vila Nova de Famalicão, district of Braga) and Penouta/Seixoso (county of Felgueiras, district of Oporto), respectively. The same was observed in the hoards of Gingleta/Ganfei, Carpinteira/S. Paio and Cabeiras. Veins of wolframite (W), where tin is also present, can be identified at Barbeita (Monção) and at Northwest of Serra Pequena (Valença). Tin is also present at the left bank of river Minho, near Ribadalva (Ourense). All these primary veins constantly eroded fed local water lines that flow to river Minho, allowing the recollection of alluvial cassiterite. For this reason, these were certainly confluent spots of passage probably well known by the populations who produced and manipulated bronze objects.

Resulting from complex social phenomena of difficult interpretation, the amortization of those hoards may have resulted, contrary to the will of a single person or a community, of communal cele- brative acts seeking to concretize pacts or agreements perpetrated between members of different groups that converged to those areas (SAMPAIO 2014). Although referring to other type of contexts and based on the established connections between people and places (THOMAS 1999), Pollard (2011: 32) notes that "pit digging and deposition served as actions intended to bring meaning to places, a process by which people placed something redolent of their sociality in a given location (...) "fixing" a connection between people and a place". As so, depositing metal objects could result from the will to connect social actors between them and to fix them, at the same time, with a specific place. In this way, the senses and meanings of people, objects and places would converge in a single manner.

Thus, beyond the magical and symbolic character involving the "chaîne opératoire" that brings objects into "worldly life", the biographies of these objects exceeded their functionality as mere 'instruments' or 'tools'. In this sense, these hoards may represent histories and meanings associated with different populations gathered in certain moments of great social significance, whose contact resulted in the amortization of special sets of objects (SAMPAIO 2014). More than accomplishing their ultimate life stage and even being hidden, deposition of metal objects brings us face to face with another purpose of the life and biography of the objects equally important as any other.

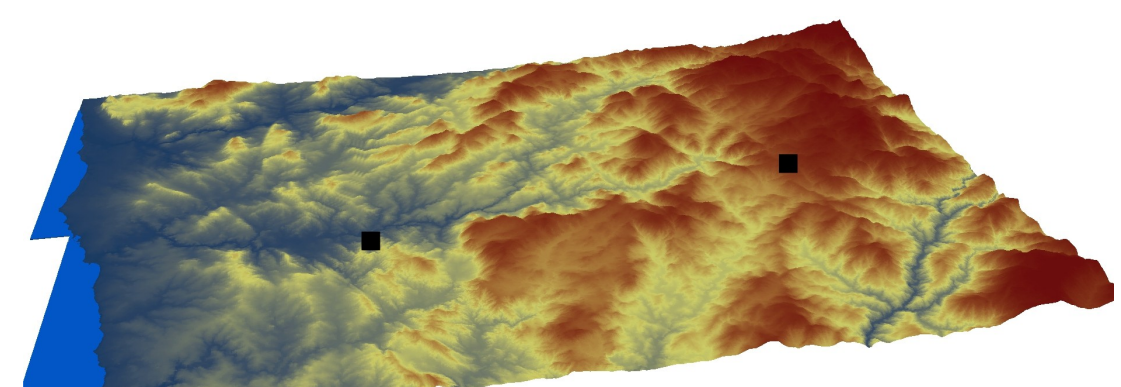

Fig. 14. The hoards of Abelheira/S. Martinho do Bougado (at left) and Senhora Aparecida/Pinheiro (at right) in the immediate geomorphology (view from South/Southwest).

Fig. 14. Os depósitos da Abelheira/S. Martinho do Bougado (à esquerda) e de Senhora Aparecida/Pinheiro (à direita) na geomorfologia envolvente (vista de Sul/Sudoeste).

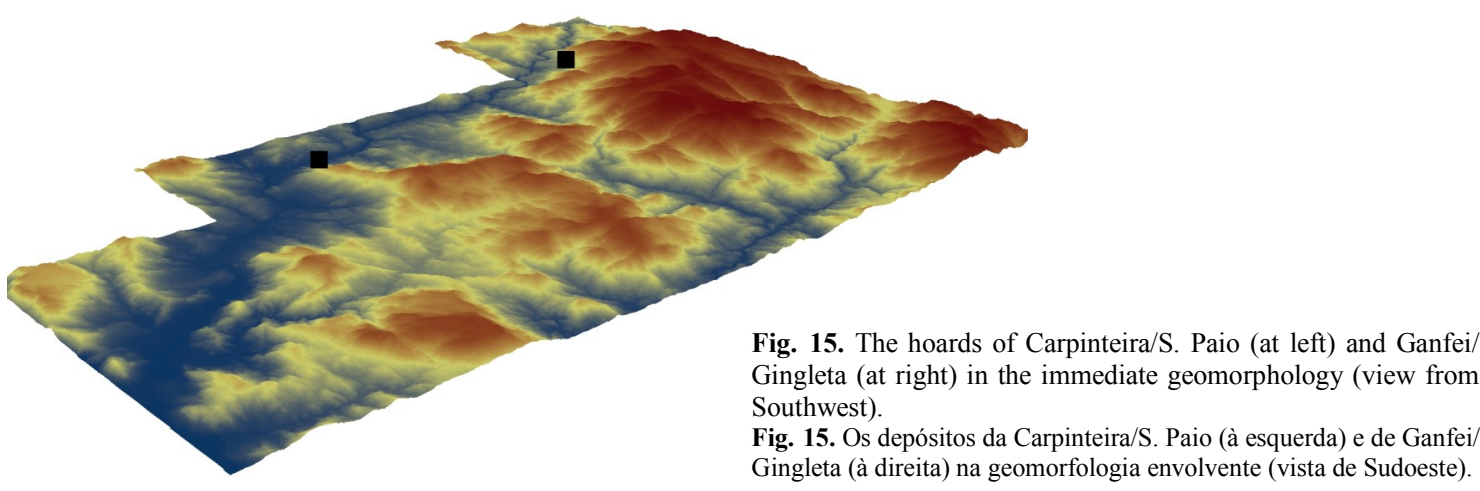


Late Bronze Age monotypological deposits of palstave axes between the hydrographic basins of rivers Minho and Ave (Iberian Northwest): spatial contexts and interpretations

\section{REFERENCES}

APPADURAI, A. 1986. Introduction: commodities and the politics of value. In A. APPADURAI (Ed.) The social life of things. Commodities in cultural perspective. Cambridge: University Press, pp. 3-63.

BARRETT, J.C. 1999. Chronologies of landscape. In P.J. UCKO \& R. LAYTON (eds.) The archaeology and anthropology of landscape. Shaping your landscape, London: Routledge, 21-30.

BARRETT, J.C. 2001. Agency, the Duality of Structure, and the Problem of the Archaeological Record. In I. HodDER (ed.) Archaeological Theory Today. Cambridge: Polity Press, 141-64.

BETTENCOURT, A.M.S; COMENDADOR REY, B.; SIMÕES, P.P. \& ALVES, M.I.C. 2014. O depósito de machados do Bronze Final de Cobidalto, Areosa (Viana do Castelo). Novos dados para a sua contextualização. In A.M.S BetTenCOURT, B. COMENDADOR REY, H.A SAMPAIO \& E. SÁ (Eds.) Corpos e Metais na fachada Atlântica da Ibéria. Do Neolitico à Idade do Bronze. Braga: APEQ/CITCEM, pp. 131-142.

Bottaini, C.E. 2012. Depósitos metálicos no Bronze Final (sécs. XIII-VII A.C.) do Centro e Norte de Portugal. Aspetos sociais e arqueometalúrgicos. Coimbra: Faculdade de Letras da Universidade de Coimbra (Ph.D. thesis).

BRADLEY, R. 2000. An Archaeology of Natural Places. London and New York: Routledge.

CARballo ARCEO, X. \& REY CAStiñeIRA, J. 2014. O depósito de machados de talón de Cabeiras (Arbo, Galiza) no contexto da bacía baixa do río Miño. In A.M.S BETTENCOURT, B. COMENDADOR REY, H.A. SAMPAIO \& E. SÁ (Eds.) Corpos e Metais na fachada Atlântica da Ibéria. Do Neolítico à_Idade do Bronze. Braga: APEQ/CITCEM, pp. 103-120.

CASTRO, E.V. 2004. Exchanging perspectives. The transformation of objects into subject in Ameridian ontologies. Common Knowledge 10 (3): 463-485.

DESCOLA, P. 1996. Constructing natures: Symbolic ecology and social practice. In P. DESCOLA \& G. PÁlSSON (Ed.) Nature and Society: Anthropological Perspectives. London \& New York: Routledge.

EMIRBAYER, M. \& MISCHE, A. 1998. What Is Agency? American Journal of Sociology 103. Chicago: 962. 1023.

FELD, S. \& BASSO, K.H. 1996. Senses of Place. Santa Fe, New Mexico: School of American Research Press.

FONTIJN, D. 2001/2002. Sacrificial Landscapes. Cultural biographies of persons, objects and natural places in the Bronze Age of Southern Netherlands, c. 2600600 BC. Leiden: University of Leiden (Ph.D. thesis) [Analecta Praehistorica Leidensia 33/34].

FORTES, J. 1905-1908a. Esconderijo morgeano da Carpinteira (Melgaço). Portugalia, 2 (1-4): 475.

FORTES, J. 1905-1908b. Esconderijo morgeano de Ganfei (Valença). Portugalia, 2 (1-4): 661.

GELL, A. 1998. Art and Agency: An Anthropological Theory. Oxford: Clarendon Press.

GIDDENS, A. 2000 [1979]. Dualidade da Estrutura: Agência e Estrutura. Oeiras: Celta Ed.

GOSDEN, C. \& MARSHALL, Y. 1999. The cultural biography of objects. World Archaeology 31 (2): 169-178.
HODDER, I. 2012. Entangled. An Archaeology of the Relationship between Humans and Things. Chichester: John Willey \& Sons.

INGOLD, T. 2000. The Perception of the Environment: Essays on Livelihood, Dweling and Skill. London: Routledge.

INGOLD, T. 2006. Rethinking the animate, re-animating thought. Ethnos. Journal of Anthropology 71 (1): 9-20.

KOPYTOFF, I. 1986. The cultural biography of things: commodization as process. In A. ApPADURAI (Ed.) The Social Life of Things: Commodities in Cultural Perspective. Cambridge: University Press, pp. 6491.

MONTEAgudo, L. 1977. Die Beile auf der Iberischen Halbinsel. Prähistorische Bronzefunde, IX (6). Munchen.

PINTO, J.M.S.M. 1995. O povoamento da bacia superior do rio Sousa da Proto-História à Romanização. Trabalhos de Antropologia e Etnologia 35 (1): 265-283.

POLLARD, J. 2001. The aesthetics of depositional practice. World Archaeology 33 (2): 315-333.

SAHLIns, M. 1972. Stone Age Economics. Chicago: Aldine/ Atherton, Inc.

SAMPAIO, H.A. 2014. A Idade do Bronze na bacia do rio Ave (Noroeste de Portugal). Braga: Universidade do Minho (Ph.D. thesis).

SARMENTO, F.M. 1888. Antigualhas. Revista de Guimarães, 5 (4): $157-163$

SARMENTO, F.M. 1999. Antíqua. Guimarães: Sociedade Martins Sarmento.

SIRET, L. 1913. Questions de Chronologie et d'Ethnographie Ibériques. De la Fin du Quaternaire à la Fin du Bronze. Paris: Paul Geuthner.

THOMAS, J. 1999. Understanding the Neolithic. London: Routledge.

THOMAS, J. 2001. Archaeologies of Place and Landscape. In I. HodDER (Ed.) Archaeological Theory Today. Cambridge Polity Press: 165-186.

TILLEY, C. 2004. The Materiality of Stone: explorations in Landscape Archaeology. Oxford University Press: Berg.

VAN DYKE, R.M. \& ALCOCK, S. 2003. Archaeologies of Memory: an introduction. In R.M. VAN DYKE \& S.E. AlCOCK (eds.) Archaeologies of Memory. Oxford: Blackwell: 1-13.

VILLAS-BÔAS, J.S.P. 1948. Um machado de bronze. Boletim do Grupo de Alcaides de Faria, 1: 13-19.

WERTSCH, J.V. 2002. Voices of Collective Remembering. Cambridge: University Press. 